\title{
Mountain Commons: Changing Space and Status at Community Levels in Himalayas $^{1}$
}

\author{
- Narpat S. Jodha \\ Sr. Research Associate (Policy Analyst) \\ International Centre for Integrated Mountain Development (ICIMOD) \\ G.P.O. Box 3226, Kathmandu, Nepal \\ Email: njodha@icimod.org
}

\begin{abstract}
This paper deals with the imperatives of nature society interaction in Himalayas seen through CPR lens. It specifically looks at the process and factors that characterize the dynamics of the above interactions, with particular reference to the changing status and governance of CPRs at community levels. The paper puts together the synthesis of observations and inferences of different studies by ICIMOD and others in mountain regions, particularly in different parts of Nepal, India, Bhutan, Bangladesh, China and Pakistan.

In fact rural CPRs (providing sustenance supplies and services) as an important component of community's natural resource base, manifest the institutional arrangements evolved by the communities to facilitate their adaptations to nature. The above process can be more clearly illustrated with reference to specific characteristics of mountain areas, called mountain specificities, such as high degrees of inaccessibility (forcing people's crucial dependence on local resources for sustenance and hence need for their protection), fragility (favouring conservation focused, diversified and extensive type of land use practices promoting collective stakes in CPRs), marginality both physical and socio-political (promoting social cohesion for collective self help and risk sharing), diversity (making CPR as a key component of community's diversified resource use systems). This may be added that the mountain circumstances and people's traditional adaptations alluded to above, reflected the primacy of supply side factors in land resource allocation and usage including the provision of CPRs.

However, overtime the situation of CPRs, in terms of their extent and status, governance and management as well as contributions to community sustenance has changed with the process of socio-economic and administrative as well as physical and infrastructural changes in mountain areas. These changes have made the management and usage (over-exploitation) of CPRs highly demand driven, ignoring the imperatives of mountain specificities. The major agencies contributing to this change process focused by the paper are the state, market forces, rapidly differentiated rural communities and of late the spread of economic globalization. Following the percept that problems also carry seeds of their solutions, the paper attempts to indicate potential lead lines for searching options for rehabilitation of CPRs, based on closer understanding of the factors contributing to decline of CPRs.
\end{abstract}

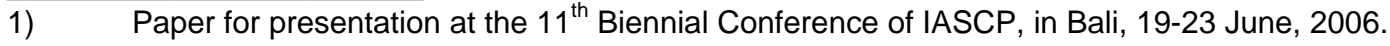




\section{INTRODUCTION}

\section{Mountain Commons: Nature - Society Interactions}

Rural common property resources or common pool resources (CPRs) ${ }^{1}$ particularly in the fragile areas such as mountains are manifestations of specific nature-society interactions. They represent community's collective or institutional adaptation to specific attributes of natural resource base (NRB) and nature's responses in terms of facilitating community's sustenance in harsh environments (Berkes 1989). The place and role of CPRs in facilitating the two-way adaptation process: i.e. adapting collective human needs to constraining circumstances and opportunities offered by nature and attempting changes in the constraining natural factors without creating negative side effects. This is more pronounced in high risk, low productivity, fragile and vulnerable landscapes such as mountains. The natural or environmental factors (historically) promoting institution of CPRs are: high risk, low productivity-limited range of production options; land resources which are hard to harness and less attractive for intensification; local ecological heterogeneities inducing inter-linked land based activities and need for complementing CPR-PPR (private property resource) based sustenance strategies. From the social angle, adaptations to the above circumstances which favour the institution of CPRs are: low attractiveness and efficacy of wholesale privatization of land resources, focus on resource-use diversification (balancing production and conservation), high degree of collective stake in protection and health of natural resource base, and social cohesion to help evolve and enforce norms and practices favouring the above imperatives (Jodha 2001, Bijonness 1983).

In mountain areas these adaptations have been shaped by, what are termed as mountain specificities and their imperatives in different historical, demographic and socio-economic contexts. As elaborated under Annex A, the mountain specificities include limited accessibility high degree of fragility, marginality, diversity and nature endowed niche resources. To elaborate, limited accessibility, relative isolation and distance-based closedness, force community's crucial dependence on local resources and hence their protection while using, including through group action. Fragility favoured (conservation focused) diversified land use with emphasis on extensive type of usage promoting collective stake in fragile (degradable) resources. Marginality, both physical and socio-political, promoted social cohesion for collective self help and risk sharing. Diversity facilitated combining intensive and extensive usage systems with space for CPR type of collective arrangements. Human adaptation mechanisms to the above circumstances (varying within mountain areas, acquired their own specific characters to qualify as one of the mountain specificities (Jodha et.al. 1992).

In the following discussion we describe the traditional situation, where imperatives of mountain specificities induced the provision for and protection of CPRs. This a followed by discussion of change (particularly closer administrative and market integration of mountain areas with plain dominated mainstream systems), which encouraged

1) Village commons in mountain areas include community forest, pasture, local water resources, and a variety of land spaces preserved for multiple purposes (such as sacred groves, specific bio-diversity reserves other uncultivated lands etc.). 
disregard of imperatives of mountain specificities, and in the process marginalized the community approaches and actions that helped in maintaining CPRs. The paper also discusses the more current situation, where the emerging scenarios dominated by economic globalization as it affects CPRs. Finally we comment on the possible lead lines to rehabilitate CPRs, based on learning from the key driving forces adversely affecting CPRs.

The paper is based on synthesis of observations, understanding and inferences from several studies (focused on farming systems and natural resource management), in the countries of Hindu Kush-Himalayan, conducted by ICIMOD with its partner institutions and other scholars during the recent decades (Jodha and Shrestha 1994, Jodha et.al. 1992, Banskota et.al. 2000, Blaikie and Sadeque 2000, Hobley 1996). As alluded to above the paper is divided in four sections, reflecting on the different phases of CPR situation indicated above.

\section{MOUNTAIN CPRS: THE TRADITIONAL CONTEXT}

As already alluded to the traditional situation in mountain areas was characterized mainly by very limited external links and largely local resource centred subsistence oriented resource use systems (by relatively smaller populations), on the one hand and crucial dependence of village community on diverse and fragile resources requiring balancing of production and conservation needs. This created the circumstances that favoured the provision of CPRs. As indicated by Annex A, the resource use systems or people's adaptation to high risk, low productivity environment was driven more by supply side limitation rather than demand side compulsions (Jodha 1998). The relevant inferences from details under Annex A, could be summarized as indicative circumstances favouring provision of CPRs at regional, community and household levels. These circumstances (summarized under Table 1) reduced the efficacy of individual - centred (or fully) private property led strategies for risk reduction and harnessing of fragile, marginal, diverse resources. The collective efforts to ensure low intensity usage of fragile lands/steep slopes through a variety of CPRs became unavoidable. Hence greater reliance on activities based on complementarity between CPR and PPR (private property resumed) based resource use systems. Low population and absence of land market for fragile, marginal lands as private property also favoured CPRs. More importantly, low pay off and practical difficulties in using fragile lands intensively as private crop lands etc. further induced the need and action for collective strategies and group action to regulate the usage of such resources to fit in to the diversified farming systems linking crops, livestock and forest etc. Thus both demand and supply side factors favoured the use of fragile lands as CPRs. The customary rights or local resource autonomy as well as (people's) practical and intimate knowledge of resource limitations to guide land use, further helped it (Jodha et.al. 1992, Guha 1983, Pant 1935, Jodha 2001, Dove and Carpenter 1992).

\section{GRADUAL MARGINALIZATION OF TRADITIONAL ARRANGEMENTS}

As outlined in Annex B, the traditional arrangements guiding natural resource use systems including protection and management of CPRs in mountain areas, were slowly made less effective and more difficult. The process of this change is closely associated 
with closer integration of mountain areas with outside mainstream economic, political and administrative situations. The closer integration (despite its several benefits), had some side-effects in terms of marginalizing or disregarding the customary rights and norms as well as mechanisms and practices, which were evolved overtime to manage CPRs and NRB in general. The overall impact of the involved changes (Bromley and Chapagain 1984; Sanwal 1989, Jodha 1992, Shivakoti et.al. 1997, Rasul and Karki 2006, Jiyuan et.al. 2002, Dasgupta and Symlieh 2006) was in terms of altering the circumstances that favoured CPRs. The key drivers behind this change were population growth (directly or indirectly induced by integration) inducing land hunger; enhanced role of market forces encouraging privatization of CPR; public interventions (administrative, fiscal and technological measures) with little sensitivity to CPRs in fragile areas and disregard of traditional institutional and folk-agronomic measures to manage fragile lands (Jodha 2001, Dove and Carpenter 1992, Somanathan 1991, Tamang et.al. 1996, Jodha and Partap 1993). The most effective combined effect of all these developments has been the decline of culture and practice of collective action and autonomy of community arrangements relating to local resource management (Jodha 1998). The attitudinal and other societal changes led to replacement of collective strategies by individualised, privately focused approaches and activities involving the commons (e.g. grabing CPRs as private property or overexploiting them). 
Table 1: Circumstances Historically Associated with CPRs in Mountain Areas

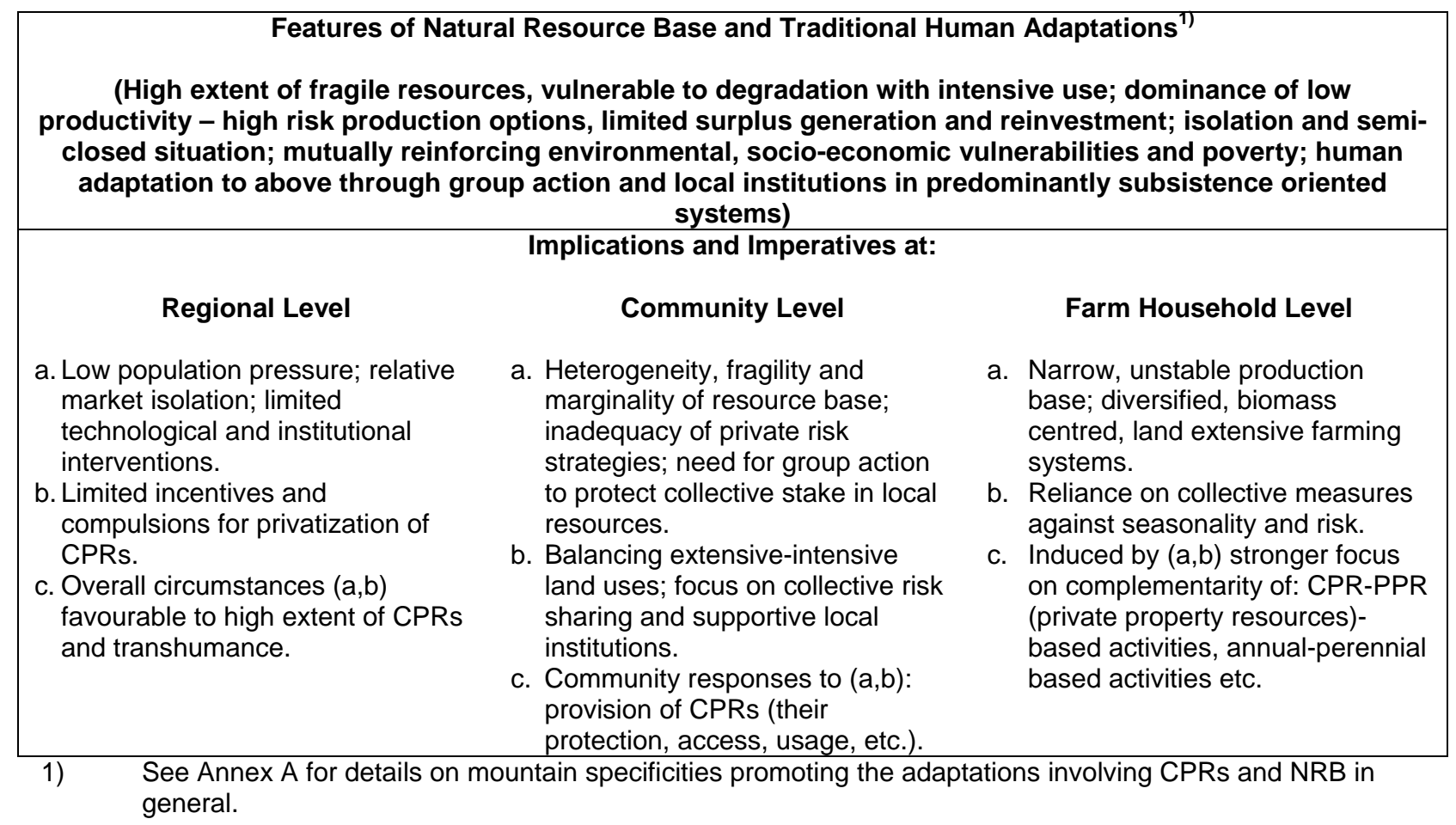

\section{Table 2: Changed Circumstances Adversely Affecting CPRs in Mountain Areas}

\begin{tabular}{|c|c|c|}
\hline \multicolumn{3}{|c|}{$\begin{array}{l}\text { Economic, Institutional and Technological Changes Influencing the Patterns of Resource Use } \\
\text { Increased physical, administrative and market integration, increased extent and changed nature of public } \\
\text { interventions, increased demographic pressure, etc. shaping the pace and pattern of rural development } \\
\text { affecting CPRs }\end{array}$} \\
\hline \multicolumn{3}{|c|}{ Implications and Imperatives at: } \\
\hline Regional Level & Community Level & Farm Household Level \\
\hline $\begin{array}{l}\text { a. Population growth accentuating } \\
\text { land hunger. } \\
\text { b. Public policies enhancing legal/ } \\
\text { illegal private and public } \\
\text { encroachment on CPR/ } \\
\text { privatization. } \\
\text { c. Technologies and market forces } \\
\text { activating the land market, } \\
\text { extending even to fragile/marginal } \\
\text { lands. } \\
\text { d. Over all circumstances }(a, b, c) \\
\text { unfavourable to CPRs. }\end{array}$ & $\begin{array}{l}\text { a. Development and market led } \\
\text { differentiation of rural community } \\
\text { and decline of collective strategies } \\
\text { for resource management, risk } \\
\text { sharing etc. } \\
\text { b. Usurpation of community's } \\
\text { mandates, initiatives by the state } \\
\text { through legal, administrative and } \\
\text { fiscal means. } \\
\text { c. Emphasis on acquiring CPRs as } \\
\text { private property, rather than use } \\
\text { collectively. } \\
\text { d. Due to (a,b,c) rapid erosion of } \\
\text { community concerns and group } \\
\text { action for CPRs. }\end{array}$ & $\begin{array}{l}\text { a. Reduced area and productivity of } \\
\text { CPRs, marginalizing their } \\
\text { contribution to diversified and } \\
\text { biomass-centred production } \\
\text { strategies. } \\
\text { b. Individualization of adjustment } \\
\text { measures against risk } \\
\text { vulnerability and seasonality etc. } \\
\text { c. Reliance on private resource, } \\
\text { public relief, non-biomass } \\
\text { oriented technologies, etc. } \\
\text { d. Due to (a,b,c) reduced reliance } \\
\text { on complementary of PR-PPR } \\
\text { (private property resources) } \\
\text { activities/products. }\end{array}$ \\
\hline
\end{tabular}

1) See Annex $B$, for details of the process of changes and their consequences. 
Table 2 summarises the key variables of the above process. Accordingly, while the biophysical factors and processes supporting need for CPRs remain broadly unchanged, the socio-economic pressures and processes have acquired primacy and have significantly contributed to the decline of CPRs in terms of both their extent and productivity as well as local knowledge and management systems. The pace and pattern of the above is much greater in developed and better accessible mountain areas compared to the others. Similarly, in the villages with strong traditional leadership and greater social cohesion, situation is better in terms of health of CPRs. However, the general situation is broadly as indicated by Table 2, (which is quite self explanatory). The table puts together the indicative changes at regional, community and individual farm household levels, which portrays the picture that is completely opposite of the situation i.e. circumstances and their consequences, presented in Table 1. The obvious result of this change is reduced concern for and actions about promoting and protecting CPRs.

\section{EMERGING SCENARIOS: IMPACT OF GLOBALISATION}

Concerned with the decline of the commons, there has been several efforts to salvage the situation. Apart from the research and advocacy to rehabilitate CPRs, there have been several public policy-programme interventions (such as user group forestry and joint forest management programme in Nepal and India respectively). Besides, NGO, donors and community supported activities focused on revival of individual CPR types and CPR units are also multiplying. These efforts however show rather mixed success (EERN 2000, Poffenberger et.al. 1996, Hobley 1996, Baral 2002, Saigal 2001).

While the positive efforts to rehabilitate CPRs are yet to make significant dent on the situation, the new challenges to sustain CPRs as productive social assets are emerging fast. They result from the more stronger market forces associated with the process of economic globalization rapidly covering the mountain areas (Gupta 2006).

If one goes by the changing role of driving forces and processes rather than proximate causes behind the decline of CPRs, the emerging scenarios do not look very favourable to CPRs. This is revealed by the fact that the processes which adversely affected CPRs in the past are further strengthened by the recent developments symbolized by the rapid spread of economic globalization in mountain areas and its impacts on the already mentioned key agencies or driving forces affecting CPRs. Before we elaborate on this a word on globalisation.

\section{The Globalisation Process}

Economic Globalisation, with primacy to market friendly and market driven processes, is one of the most debated and yet rapidly promoted phenomenon of the world today. There is hardly any sector or region of the world unaffected by globalization. Mountains commons are no exception. Before we illustrate this, a word on visible or invisible incompatibilities between the central thrusts and operating mechanisms of globalization and imperative of already alluded mountain specificities (Annex A), which necessitated and facilitated the provision of CPRs. While mountain specificities favoured diversification of resource use and production systems (including CPRs), globalization 
encourages selectivity and narrow specialization; while mountain specificities call for supply condition-driven adaptations, globalization pushes for enhanced demand-driven over exploitation of resources including fragile lands; and their selected products such as herbs; finally globalization promotes privatization of activities, which are better suited to collective/group initiatives. In the process of promoting the above, globalization tends to marginalize the state as well as the communities vis-à-vis market forces. To understand the manifestation of the above with reference to CPRs, one should look at the globalization induced changes in the role of agencies/driving forces adversely affecting CPRs. These agencies and their operational mechanisms directly or indirectly and individually or jointly affecting the present situation of CPRs are:

(i) The state: operating through its policies and programmes including through transfer of CPR lands to corporate sector or environmental agencies discarding customary rights and livelihoods of the locals (Guha 1993, Metz 1991, Bromley and Chapagain 1984, Jodha 1992, Baral 2002).

(ii) The market forces: promoting privatization or elimination of CPRs and with the state help (marginalizing the role of communities vis-à-vis the local commons and traditional systems) (Hiremath 1997, Leach et.al. 1997).

(iii) The increasing differentiation of rural communities: depleting the collective stake in CPRs; encouraging privatization through encroachment rather than focusing on collective use, specially when strong incentives from market are available (Jodha 2002).

(iv) The CPRs themselves (representing nature or natural resource base) with their largely degraded status inducing little hope and action on the part of rural communities to rehabilitate CPRs, specially when there are incentives and compulsions to ignore them (Jodha 2006).

The extent or intensity of tendencies unfavourable to CPRs, on the part of the above agencies, accentuated due to globalization process are discussed below. The discussion is based on an exploratory study of globalization and its impacts on mountain areas and communities in selected mountain areas of China, India, Nepal and Pakistan by ICIMOD and its country-partners (Jodha 2002). The study revealed a number of emerging trends. Ones relating to CPRs vis-à-vis the above mentioned agencies i.e. state, rural community, market forces and 'nature' itself, are discussed below. However, one of the central findings of the explorations was that the imperatives of mountain specificities (see Annex A and Table 1) which favoured the provision and protection of CPRs are by passed under the activities and processes promoted by globalization through the above agencies.

\section{(i) The State Interventions and CPRs in Globalisation Era}

As a custodian of country's natural resources, the state in different countries, by ignoring the communities' customary rights/institutions/practices as well as the role and relevance of commons in livelihoods of the people in fragile areas, has curtailed the areas of commons through various development and welfare policies and programmes in the past (Sanwal 1989, Somanathan 1991, Golam and Karki 2006, Dove and Carpenter 1992). However, this tendency has accentuated with the incentives and compulsions associated with globalization (Gupta 2006). Accordingly, in place of gradual curtailing of areas and marginalising traditional management systems, the 
current tendency is to transfer vast areas (at times including private crop lands) to corporate firms, in the name of economic reforms and various development programme focused on industry, infrastructure and services. This has been the case in Tibet (China) Uttaranchal (India), Northern parts of Pakistan and some districts of Nepal (Jodha 2000, 2002).

Almost similar is the situation with regard to transfer of vast community lands to different environmental protection projects (e.g. parks etc.) under global treaties etc., where people's access and usage rights to commons are disregarded. In most cases resettlement of oustees and compensation issues are not addressed timely and adequately. Though small efforts by NGOs and researchers as well as enlightened government and donor agencies (e.g. under trans-boundary biodiversity conservation initiatives, involving local communities) are made.

The state's more significant role affecting CPRs under globalization is through according unprecedented primacy to market forces under 'economic reforms' programme, which pushes the process of privatization and commoditization of natural resources including CPRs (Gupta 2006). Apart from disregarding customary rights this implies abolition of required regulation and welfare activities (e.g. subsidy etc.) affecting the poor, who are also adversely affected by decline of CPRs. Granting long term lease to corporate agencies in the above context covers land, water and other local resources in the name of area development. As has been seen, in different hill areas of India, Nepal, Pakistan, China and Bangladesh transfer of CPRs to private firms on long term lease has taken place as captive sources of supplies/services. The latter includes plantation for paper mills; exclusive areas for flowers and herbs for industrial use and export; water spots for captive power generation; wild-enclosures as mountain tourism facilities including for luxury hotels etc. Undoubtedly, the commercial returns through these changes are much higher than what communities harnessed from them. But such steps not only by pass the customary rights of the communities but eliminate crucial sources of livelihoods for the local people. Moreover, compensatory provisions or associating communities with new initiatives (except as short term wage labour for building infrastructure for the above activities), hardly get any attention (Jodha 2002).

\section{(ii) Globalisation-induced enhanced differentiation among the CPR-users (rural communities)}

The process and consequences of socio-economic differentiation of communities leading to their reduced collective stake in CPRs and decline of culture of group action has been already alluded to. With globalization leading to preference for high pay off production activities/resource use systems and individual-determined strategies with close links with town traders and markets, the above mentioned differentiations are significantly increased. This further weakens the collective community stake in CPRs. In fact, in many areas, better off sections of the communities were seen to collaborate with market agents and others to disintegrate and grab the CPRs as private property. The same applies to preferred product choices from CPRs and their over-extraction in response to external demands. Induced by market agencies in many areas of India, Pakistan, Nepal and China, the contractual CPR-product gathering arrangements involving the locals are emerging (Jodha 2002, 2000). 


\section{(iii) Nature - represented by CPRs as a 'party' in the process of CPR decline}

It is not a deep philosophical or poetic statement to call 'nature' as a party or an agency helplessly and silently contributing to the degradation process of CPRs. In reality this implies a process, where degradation of CPRs reinforces itself. Accordingly, in their present situation several CPRs are degraded to an extent where they inspire neither hope nor any initiative on the part of communities to revive CPRs. The emerging trend indicating people's discriminatory approach, favouring only a few more productive CPRs or units of same CPR type and neglecting the others, is yet another feature of the present situation (Jodha 2005), in which globalization process has played important role.

Finally, nature's own contribution to sustainable natural resource management declined with globalization-induced disregard of imperatives of mountain specificities as alluded to earlier. In place of diversified balanced use of NRB, globalization led agencies push for selective, profitable but ecologically harmful over-exploitation of NRB. This applies to CPRs as well, where high value products are focused.

\section{(iv) Market forces with enhanced role under globalization}

The role of market forces, following the increased integration of mountain areas/communities with the external systems in promoting higher land demands and privatization of CPR is already mentioned. However, under globalization process their role has been further accentuated. This has happened both indirectly, (by altering the approach and actions of the state and communities as already mentioned) and directly by encouraging market orientation of product choices and resource allocation in hitherto largely subsistence oriented communities. Accordingly, rather than primarily focusing on bio-mass centred usage of CPRs (e.g. for fodder, fuel etc.), the high value products (gum, mushrooms, flowers, herbs etc.) for market are gaining favour. At times, it generates conflicts within the communities. This is illustrated by the case of babhar grass from CPRs in Shivalik hills (India), which poor people want to harvest young and use as animal fodder, while the rich members of the community want it to mature for selling it to paper mills. Similar is the conflict between choices promoting fish, seasonal vegetables and floriculture around rivulets versus using them for water and grass supplies for the poor in the communities (Jodha 2002, 2005).

As mentioned earlier, CPR-type wise and individual CPR-unit wise increased discriminatory approach of communities to protect and manage only parts of CPRs (in place of focusing on the aggregates of CPRs) is another consequence of increased market orientation of CPR-users.

Finally external demand induced 'over-exploitation' of selected CPR products (e.g. medicinal herbs), including through a variety of contractual arrangements between villagers and agents of big firms/exporters to collect and supply rare/endangered species. To this one can add increasing encroachment or legal acquisition of CPR land for high value farm products (through horticulture, floriculture etc.) for external markets. The people's collective risk management practices and resource use systems also got 
set back due to breakdown of CPR-PPR complementarities under the pressure of new market forces (Jodha 2002, Gupta 2006).

\section{RECLAIMING CPRS}

For those concerned with the contributions and crisis as well as future of CPRs, the account presented above is not very encouraging. Yet one can search for salvage possibilities. The latter could be based on potential adaptations to the emerging circumstances, which are adversely affecting CPRs. Following the percept that every problem also carries seeds of its solution, the elements of remedial approaches to the current problems of CPRs could be identified from within the complex of factors affecting them. Accordingly, we attempt to suggest the indicative areas, where search for potential solutions could be focused.

Closer observation and understanding of the factors and processes characterizing the pace and pattern of changes in CPR situation suggest the need for addressing the following, (often interrelated) issues while searching the revival options for CPRs.

(i) Reviving the community's collective stake in CPRs to help rehabilitate them.

(ii) Recognising the emerging centrality of market mechanisms and harnessing their potential for CPR revival.

(iii) Changing the priorities and preferences regarding CPR products and services and designing natural resource management/development interventions accordingly.

(iv) Changing the role and responsibilities of state in keeping with the needs and imperatives of the above (i) to (iii).

We briefly comment on them, specially the constraints each of them may face and the lead lines to address them.

\section{(i) Reviving community's collective stakes in CPRs}

Of all the areas for searching solutions for CPR problems mentioned above, this is most difficult. It is not easy to undo the factors which caused depletion of community's collective stake in CPRs. For instance, the increased socio-economic differentiation in rural community, which eroded the culture of group action and collective stakes in CPRs, is major side-effect of rural socio-economic transformation which can not be reversed.

Similarly, slowly increasing market orientation of decisions and actions of rural people, which accord higher priority to individual-centred (private) strategies compared to collective strategies is not easy to reverse, specially in the current contexts associated with globalization.

Besides, the present degraded status of CPRs provide little hope and incentive for collective community stake in CPRs. Also the public interventions promoting community involvement in natural resource management, such as Joint Forest Management (India), User Group Forestry (Nepal) etc., are top-down, formal and largely state 
designed efforts, are too inadequate to promote genuine collective stakes in CPRs (Jodha 2006, Dasgupta and Symlieh 2006).

Finally, a very basic operational problem about collective stake in CPRs, relates to the scale issues. Accordingly, both in research as well as policy-programme contexts focus on aggregates i.e. total CPRs or total extent of individual CPR in the village; as well as aggregated village communities with all the diversities. This may not serve the purpose of rebuilding community stake in CPRs. Under such situation carefully designed disaggregated approach can help better. Accordingly rather than focusing on aggregates, of CPRs and communities, one should disaggregate the contexts for stake building. The proof of usability of this approach is provided by formation of smaller user groups involved in profitably managing specific CPRs or rather individual units of the same; which also satisfy the other requirements for collective stake (of the user groups) e.g. high value products, productivity and profitability as required by increasing market orientation of CPR users (Jodha 2005, 2006).

Finally, one should build upon the scattered success stories of revival of collective local natural resource management as reported by different studies (Agarwal and Narain 2000, Baral 2002, Butt and Price 2000, Hobley 1996, Saxena 1995, Lynch et.al. 1995, Shackleton et.al. 2002).

\section{(ii) Recognising centrality of market mechanisms and harnessing their potential for CPRs}

Market forces are usually blamed for decline of CPRs, as they do not favour the traditional informal arrangements and practices relating to CPRs. However, with rapid economic globalization and related developments, the role of market forces is becoming all the more stronger and cannot be wished away. Besides, if appropriately assessed market entry in the field of CPRs carry both risks and opportunities. Hence, while guarding against the risks, the focus should be on identification and harnessing of the opportunities. In the context of rehabilitating CPRs, the indicators of potential opportunities are relatively clearer. The first and foremost is the need for emphasizing high value components of CPR products and services, where market can help in making choices (e.g. for herbs, flowers etc. along with directly, locally usable biomass). This would fit better to changed community/user group approaches to management of disaggregated CPR components (Jodha 2005, 2006).

Second, more equitable links of communities (CPR users) with market agencies can help enhanced opportunities and gains from reoriented usage/product choices from CPRs as shown by pharmaceutical firms in Himalayan countries (Jodha 2000, 2002).

Thirdly, the alliances between marketing firms for post harvest activities and communities for planting to harvesting level activities, can help build capacities and better-earning occupational diversification at community level as seen in the case of firms dealing with processing and marketing of herbs, flowers, mushrooms and seeds in parts of Nepal, and China, India, Pakistan and Bhutan (Jodha 2002). 
Besides enhancing economic gains from CPRs through market, the environmental benefits through collaboration with market agencies, too could be harnessed. This could be done through assessment and marketing of environmental services from CPRs, and ensuring appropriate investments and management with the help of corporate sector, by associating them as partners in CPR rehabilitation.

Such association using market mechanisms can also help in compensating the communities as local managers of CPRs. This is all the more important in the context of highland - lowland environment and economic links in mountain areas (Jodha 2002).

\section{(iii) Changing priorities and preferences regarding CPR products and management}

Largely in keeping with the preceding discussion on market led opportunities for CPR management, the necessary shift in priorities and choices of CPR products and services is yet another area for searching options for CPR revival. This again means focus on high value products (besides locally used biomass), improved scope for CPR-PPR complementarities etc. A major pre-requisite for such shift is to reorient the approach of state and communities towards CPRs. Rather than treating them as nature's free gift, emphasis has to be place on CPRs as social assets. This in turn would call for investment and technological inputs, to make CPRs high paying entities to fit to the market oriented approaches of CPR users (Jodha 2005, Jiyuan et.al. 2002, Banskota et.al. 2000, Saxena 2000).

\section{(vii) Changing role and responsibilities of the state}

As a final custodian of country's natural resources, the dominant role of the state in CPR matters has been related to protection or allocation or distribution of these resources to different agencies. Besides, it created and changed the institutions and arrangements to regulate their usage. While performing these functions, state had been a major agency in contributing to the decline of CPRs during the whole period ranging from days of colonial rule (in pre-second world war period) to present day economic globalization.

However, in the light of above discussion on searching options to rehabilitate CPRs, there are several areas where state will have to be very pro-active to facilitate revival of CPRs in the changed contexts.

The required intervention, regulation and support of the state, will be needed for reviving community's collective stakes in CPRs- through incentives and capacity building of communities (Shackleton et.al. 2002, Tamang et.al. 1996), promotion and regulation of usage of market mechanisms in rehabilitating CPRs; changing the complex of products and services from CPRs to fit to the present day, economically dominated approaches to natural resource management and development, including use of new institutional and technological approaches (Saigal 2001, Lynch and Talbott 1995).

Area specific strategies incorporating elements of the above components could be build to rehabilitate the mountain commons. 


\section{References}

Agarwal, A. and S. Narain (1990) Strategies for the Involvement of Landless and Women in Afforestation: Five Case Studies from India. Geneva: International Labour Office.

Baral, J.C. (2002) 'Who Should Control Forests of Nepal: Reminiscence of the Past Endeavour and Some Thoughts for the Future Action.' E-mail Contribution Mountain Forum-Asia Discussion in Connection with Bishkek Global Mountain Summit, October 2002. (Available from jbaral@wlink.com.np.)

Banskota, M., T.S. Papola and J. Richter (eds) (2000) Growth, Poverty Allevation and Sustainable Resource Management in Mountain Areas of South Asia. Kathmandu: ICIMOD and DSE-ZEL (Feldafing).

Berkes, F. (1989) Editor. Common Property Resources: Ecology and Community-Based Sustainable Development. London: Belhaven Press.

Bijonness, I.M. (1983) 'External Economic Dependency and Human Adjustment to Marginal Environments in High Himalaya, Nepal.' Mountain Research and Development 3(3): 263-72.

Blaikie and S. Z. Sadeque (2000) Policy in High Places: Environment and Development in the Himalayan Region. Kathmandu: ICIMOD.

Bromley, D.W. and Chapagain, D.P. (1984) 'The Village Against the Centre: Resource Depletion in South Asia.' American Journal of Agricultural Economics 6(5): 869873.

Dasgupta, J. and H.J. Symlieh (2006) Trends in Tenurial Arrangements of Forests and its Implications for Sustainable Management: A Case Study from Meghalaya, India. (Paper for the $11^{\text {th }}$ Biennial Conference of IASCP, in Bali)

Dove, M.R. and C. Carpenter (1992) (editors) Sociology of Natural Resources in Pakistan and Adjoining Countries. Lahore: Vanguard Books Pvt. Ltd.

EERN (2000) Joint Forest Management and Community Forestry in India: Summary Findings of EERN. Bangalore: Ecological and Economics Research Network.

Guha, R. (1983) 'Forestry in British and Post-British India: A Historical Analysis.' Economic and Political Weekly 18(44\&45).

Gupta, R. (2006) The Dynamic between States, Resources and Indigenous People in South Asia: Implications for Common Property Resource Governance (Paper for the $11^{\text {th }}$ Biennial Conference of IASCP, in Bali).

Hiremath, S.R. (1997) Editor. Forest Lands and Forest Produce: As if People Mattered. Dharwad, India: National Committee for Protection of Natural Resources (NCPNR).

Hobley, M. (1996) 'The Four Ages of Indian Forestry: Colonialism, Commercialism, Conservation and Collaboration.' In Participatory Forestry: The Process of Change in India and Nepal, edited by M. Hobley. London: Overseas Development Institute. 
Jiyuan, L., Yansui, L., Xiangzheng, D. (2002). Management and Use of Natural Resources for Poverty Alleviationn in Mountainous Areas of Western China. In: N.S. Jodha, B. Bhadra, R. Khanal, and J. Richter (eds). Poverty Alleviation in Mountain Areas of China (Proceedings of the International Conference held in Chengdu, China, November 2002).

Jodha, N.S. (1992) 'Rural Common Property Resources: A Missing Dimension of Development Strategies.' World Bank Discussion Paper No.169. Washington, D.C.: The World Bank.

(1998) 'Reviving the Social System-Ecosystem Links in the Himalayas.' In Linking Social and Ecological Systems: Management Practices and Social Mechanisms for Building Resilience, edited by F. Berkes and C. Folke. Cambridge, UK: Cambridge University Press.

(2000) Globalisation and Fragile Mountain Environment: Policy Challenges and Choices. Mountain Research and Development, Vol. 20(4).

(2001) 'Poverty and Environmental Resource Degradation: An Alternative Explanation and Possible Solutions.' In Life on the Edge: Sustaining Agriculture and Community Resources in Fragile Environments, edited by N.S. Jodha. Delhi: Oxford University Press.

(2002) Globalization and Fragile Mountains. An Exploratory Research Report submitted to the MacArthur Foundation. Kathmandu: ICIMOD.

(2005). A Restricted Revisit to Common Property Resources in Dry Regions of India. (A paper for SANDEE Workshop, Limited Circulation).

(2006). Natural Resource Management and Poverty Alleviation in Mountain Areas In: 'Reclaiming Nature: Environmental Justice and Ecological Restoration' (Editors) J.K. Boyce, S. Narain and E.A. Stanton. London: Enthem Press (in Press).

Jodha, N.S., M. Banskota and T. Partap (eds) 1992. Sustainable mountain agriculture, 2 vols. Delhi: IBH Publishing Company, $807 \mathrm{p}$.

Jodha, N.S. and T. Partap (1993) 'Folk Agronomy in Himalayas: Implications for Research and Extension.' In Rural People's Knowledge, Agricultural Research and Extension Practices. IIED Research Series 1(3).

Jodha, N.S. and S. Shrestha, (1994). Sustainable and more productive mountain agriculture: problems and prospects. A paper presented at ICIMOD's $10^{\text {th }}$ Anniversary, International Symposium on 'Mountain environment and development'. Kathmandu, Nepal.

Leach, M., R. Mearn and I. Scoones (1997) 'Environmental Entitlements: A Frame Work for Understanding Institutional Dynamics of Environmental Change.' IDS Discussion Paper 359. Brighton: Institute of Development Studies.

Lynch, O.J. and K. Talbott (1995) Balancing Act: Community-based Forest Management and National LW in Asia and Pacific. Washington, D.C.: World Resource Institute. 
Metz, J.J. (1991) 'A reassessment of Causes and Severity of Nepal's Environmental Crisis.' World Development 19(7).

Pant, S.D. (1935) Social Economy of Himalayans. London: Allen and Unwin.

Rasul, G. and M. Karki (2006). Political Ecology of Degradation of Forest Commons in the Chittagong Hill Tracts of Bangladesh. (Paper for ...... Biennial Conference of IASCP, June 2006, Bali).

Saigal, S. (2001) Joint Forest Management: A Decade and Beyond. Paper Presented at a Workshop at Institute of Economic Growth, Delhi, India, September 2001.

Sanwal, M. (1989) 'What We Know about Mountain Development, Common Property, Investment Priorities and Institutional Arrangements.' Mountain Research and Development, 9(1): 3-14.

Saxena, N.C. (2000) Research Issues in Forestry in India. Indian Journal of Agricultural Economics 55(3): 359-83.

Shackleton, S., B. Campbell, E. Wollenberg and D. Edmunds (2002) 'Devolution and Community Based Natural Resource Management: Creating Space for Local People to Participate and Benefit.' ODI Natural Resource Perspectives 76.

Shivakoti, G., G. Varughese, L. Ostorom, A. Shukla, and G. Thapa (1997) Editors. People and Participation in Sustainable Development: Understanding Dynamics of Natural Resource Systems. Kathmandu: Tribhuvan University, Institute of Agriculture and Animal Sciences.

Somanathan, E. (1991) 'Deforestation, Property Rights and Incentives in Central Himalaya.' Economic and Political Weekly 26(1): 37-46.

Tamang, D., G.J. Gill and G.B. Thapa (1996) Editors. Indigenous Management of Natural Resources in Nepal. Kathmandu: Winrock International Nepal. 
Annex A: Mountain Specificities and their Indicative CPR - Related Imperatives

\begin{tabular}{|c|c|c|}
\hline \multicolumn{3}{|c|}{ Limited Accessibility } \\
\hline & $\begin{array}{l}\text { Manifestations and } \\
\text { implications (i.e., } \\
\text { promoting vulnerability } \\
\text { and poverty- } \\
\text { circumstances) }\end{array}$ & $\begin{array}{l}\text { - Isolation, semi-closedness, poor mobility, high cost of: mobility, infrastructural logistics, } \\
\text { support systems, and production/exchange activities } \\
\text { - Limited access to, and dependability of, external support (products, inputs, resources, } \\
\text { experiences) } \\
\text { - Detrimental to harnessing niche and gains from trade, invisibility of problems/ potentials to } \\
\text { outsiders }\end{array}$ \\
\hline & $\begin{array}{l}\text { Imperative (appropriate } \\
\text { responses, adaptation } \\
\text { approaches to reduce } \\
\text { risk and vulnerability) } \\
\text { with significant role for } \\
\text { group action and CPRs }\end{array}$ & $\begin{array}{l}\text { - } \quad \text { Primacy of local resource centred, diversified production/consumption activities fitting to } \\
\text { spatial and temporal opportunities and constraints (features of resource base) } \\
\text { - } \quad \text { Local regeneration of resources, protection, recycling regulated use (e.g. CPRs) } \\
\text { - } \quad \text { Nature and scale of operations as permitted by the degree of accessibility/ mobility }\end{array}$ \\
\hline \multicolumn{3}{|c|}{ Fragility and Marginality } \\
\hline a) & $\begin{array}{l}\text { Manifestations and } \\
\text { implications (i.e. } \\
\text { vulnerability and } \\
\text { poverty promoting } \\
\text { circumstances) }\end{array}$ & $\begin{array}{l}\text { - Large parts of resources vulnerable to rapid degradation, unsuited to intensification and } \\
\text { use of costly inputs; low carrying capacity } \\
\text { - Limited, low productivity, high risk production options; little surplus generation or } \\
\text { reinvestment and subsistence orientation preventing high cost-high productivity options } \\
\text { including for resource upgrading } \\
\text { - Socio-political-marginality of communities and their disregard by 'mainstream' societies }\end{array}$ \\
\hline b) & $\begin{array}{l}\text { Imperatives (i.e., } \\
\text { appropriate responses, } \\
\text { adaptation approaches } \\
\text { to protect and use } \\
\text { resource) where CPRs } \\
\text { play role important }\end{array}$ & $\begin{array}{l}\text { - Focus on low intensity, high stability in resource use (e.g. balancing cropping-grazing, } \\
\text { annual-perennial complementarity) } \\
\text { - Diversification involving a mix of high and low intensity uses of land, a mix of production } \\
\text { and conservation measures } \\
\text { - Local regeneration of resources, recycling, regulated use, dependence on nature's } \\
\text { regenerative processes and collective regulatory measures supporting institutions } \\
\text { (including CPRs) }\end{array}$ \\
\hline \multicolumn{3}{|c|}{ Diversity \& Niche } \\
\hline a) & $\begin{array}{l}\text { Manifestations and } \\
\text { implications (i.e. } \\
\text { potential for sustenance } \\
\text { and growth supporting } \\
\text { activities) }\end{array}$ & $\begin{array}{l}\text { - A basis for spatially and temporally diversified and interlinked activities conducive to } \\
\text { sustainability and security, strong location specificity of production and consumption } \\
\text { activities limiting the scope for large-scale operation } \\
\text { - Potential for products, services, activities with comparative advantages; (difficult to harness } \\
\text { without large investment) }\end{array}$ \\
\hline b) & $\begin{array}{l}\text { Imperatives (i.e., } \\
\text { appropriate responses, } \\
\text { adaptation approaches } \\
\text { to harness niche } \\
\text { including through } \\
\text { collective action and } \\
\text { focus on low weight/ } \\
\text { volume-high value } \\
\text { products for market) }\end{array}$ & $\begin{array}{l}\text { - Small-scale, interlinked, diversified production/consumption activities differentiated } \\
\text { temporally and spatially for fuller use of environment } \\
\text { - } \quad \text { Need diversified and decentralized interventions to match diversity } \\
\text { - } \quad \text { Transhumance, CPRs, niche-based petty trading etc. as means to harness diversity }\end{array}$ \\
\hline
\end{tabular}

Source: Table adapted from Jodha (1997) and based on evidence and inferences from over 60 studies referred to by Jodha and Shrestha (1994)

1) Mountain specificities are products of bio-physical conditions and processes characterizing mountain areas, such as slope, attitude, terrain, geologic, edafic and biotic factors, climatic variables etc. along with the specific human responses/adaptation to all the above conditions. As general factors generating constraints and opportunities for human use, the degree of mountain specificities do show variations within mountain regions. 


\section{Annex B: Factors and processes associated with community approaches and usage of natural resources (including CPRs) mountain areas under the traditional and the present systems}

\begin{tabular}{|c|c|c|c|c|}
\hline \multicolumn{3}{|c|}{$\begin{array}{c}\text { Traditional Systems } \\
\end{array}$} & \multicolumn{2}{|r|}{ Present Day Systems } \\
\hline \multicolumn{3}{|c|}{$\begin{array}{l}\text { A. Basic objective circumstances: } \\
\text { (i) Poor accessibility, isolation, semi-closeness: } \\
\text { low extent and undependable external linkages } \\
\text { and support: subsistence-oriented small } \\
\text { population } \\
\text { (ii) Diverse and fragile of NRB vulnerable to } \\
\text { degradation with intensification } \\
\text { (iii) Almost total or critical dependence on local, } \\
\text { fragile, diverse natural resource base (NRB) }\end{array}$} & \multicolumn{2}{|c|}{$\begin{array}{l}\text { (i) Enhanced physical, administrative and market } \\
\text { integration of traditionally isolated, mountain } \\
\text { areas/communities with the dominant mainstream } \\
\text { systems at the latter's terms; increased population; } \\
\text { (ii) Reduced critical dependence on local NRB (CPRs); } \\
\text { diversification of sources of sustenance; } \\
\text { (iii) High external demand, natural resource extraction }\end{array}$} \\
\hline \multicolumn{2}{|c|}{ Consequence: } & $\begin{array}{l}\text { High collective concern for health and } \\
\text { productivity of NRB (CPRs), as a } \\
\text { source of security and sustenance }\end{array}$ & Consequence: & $\begin{array}{l}\text { Reduced collective concern for local } \\
\text { NRB; rise of individual resource } \\
\text { extractive strategies }\end{array}$ \\
\hline \multicolumn{3}{|c|}{$\begin{array}{l}\text { B. Key driving forces/factors generated by }(A) \text { : } \\
\text { (i) Sustenance strategies focused on local } \\
\text { resources (e.g. CPRs); } \\
\text { (ii) Sustenance-driven collective stake in protection } \\
\text { and regeneration of NRB (CPRs); } \\
\text { (iii) Close proximity and access-based functional } \\
\text { knowledge/understanding of limitations and } \\
\text { usability of NRB, inducing diversification; } \\
\text { (iv) Local control of local resources/decisions; little } \\
\text { gap between decision-makers and resource } \\
\text { users helping adaptations; }\end{array}$} & \multicolumn{2}{|c|}{$\begin{array}{l}\text { (i) External linkage-based diversification of sources of } \\
\text { sustenance (welfare, relief, trade, production etc.); } \\
\text { (ii) Disintegration of collective stake in NRB (CPRs); } \\
\text { (iii) Marginalisation of traditional knowledge, and } \\
\text { imposition of generalized solutions from above; } \\
\text { (iv) The state imposed legal, administrative, fiscal } \\
\text { measures displacing local controls/decisions about } \\
\text { local NRB/CPRs, wider gap between decision- } \\
\text { makers and local resource users }\end{array}$} \\
\hline \multicolumn{2}{|c|}{ Consequence: } & $\begin{array}{l}\text { Collective stake in NRB (CPRs) } \\
\text { supported by local control and } \\
\text { functional knowledge of NRB }\end{array}$ & Consequence: & $\begin{array}{l}\text { Loss of collective stake and local } \\
\text { control over NRB (e.g. CPRs); } \\
\text { resource users respond in a 'reactive' } \\
\text { mode }\end{array}$ \\
\hline \multicolumn{3}{|c|}{$\begin{array}{l}\text { C. Social responses to (B) } \\
\text { (i) Evolution, adoption of resource use systems } \\
\text { (including CPRs) and folk technologies } \\
\text { promoting diversification, resource protection, } \\
\text { regeneration, recycling, etc.; covering forest, } \\
\text { pasture, cropland and their organic links; } \\
\text { (ii) Resource use regulations, rationing measures; } \\
\text { (iii) Formal/informal institutional mechanisms/group } \\
\text { action to enforce the above. }\end{array}$} & \multicolumn{2}{|c|}{$\begin{array}{l}\text { (i) Extension of externally evolved, generalize } \\
\text { technological/institutional interventions (in } \\
\text { for CPRs); disregarding local concerns/ex } \\
\text { and traditional arrangements; promoting s } \\
\text { fragmentation; } \\
\text { (ii) Emphasis on supply-side issues ignoring } \\
\text { management of demand pressure; } \\
\text { (iii) Formal, rarely enforced measures. }\end{array}$} \\
\hline Consequ & uence: & $\begin{array}{l}\text { Effective social adaptation to NRB, } \\
\text { balancing production and protection }\end{array}$ & Consequence: & $\begin{array}{l}\text { Natural resources (e.g. CPRs) over- } \\
\text { extracted as open access resources }\end{array}$ \\
\hline \multicolumn{3}{|c|}{$\begin{array}{l}\text { D. End results } \\
\text { (i) Nature-friendly management systems; } \\
\text { (ii) Evolved and enforced by local communities; } \\
\text { (iii) Facilitated by close functional knowledge and } \\
\text { community control over local resources and } \\
\text { local affairs. }\end{array}$} & \multicolumn{2}{|c|}{$\begin{array}{l}\text { (i) Over-extractive resource use systems, driven by } \\
\text { uncontrolled external market demands and internal } \\
\text { population-driven demands; } \\
\text { (ii) Externally conceived, ineffective and un- } \\
\text { enforceable interventions for protection of NRB; } \\
\text { (iii) Little investment and technology input in NRB. }\end{array}$} \\
\hline Consequ & Jences: & $\begin{array}{l}\text { 'Resource-protective/regenerative' } \\
\text { social system-ecosystem links }\end{array}$ & Consequence: & $\begin{array}{l}\text { Rapid degradation of fragile } \\
\text { NRB/CPRs; nature pleads not guilty; } \\
\text { so does the rural poor }\end{array}$ \\
\hline
\end{tabular}

Source: Adapted from: Jodha (1998). Based on evidence and inferences from over 60 studies referred to by Jodha and Shrestha (1994). 